\title{
Developing an instrument for measuring the spiritual attitude of high school students
}

\author{
${ }^{* 1}$ Safa'at Ariful Hudha; ${ }^{2}$ Djemari Mardapi \\ ${ }^{1,2}$ Graduate School of Universitas Negeri Yogyakarta \\ ${ }^{1}$ Jl. Colombo No. 1, Karangmalang, Depok, Sleman 55281, Yogyakarta, Indonesia \\ *Corresponding Author. E-mail: safaat.a.huda@gmail.com \\ Submitted: 11 July 2018 | Revised: 31 August 2018 | Accepted: 18 September 2018
}

\begin{abstract}
Attitudinal competence is one the most fundamental concepts in social psychology. It is related to personal identity, moral, and ethics that gains popularity and becomes important in educational development. This research aims to develop an instrument to measure the spiritual attitude of high school students. The study was a research and development study consisting of four stages: (a) determining conceptual definition, (b) determining operational definition, (c) drawing indicators, and (d) constructing instrument. The quantitative data analysis was used to test the construct validity through Confirmatory Factor Analysis and the coefficient of construct reliability was used to estimate the instrument reliability. The results of the study show that: (1) the instrument to measure Moslems' spiritual attitude is an inventory model of summated rating scale containing 35 items; (2) the construct validity was proven by the value of the standardized loading factor and considered as significant. The instrument reliability regarded as the construct reliability coefficient is 0.890 and the average variance extracted is 0.542 ; (3) the construct of the instrument produces a fit statistical evidence indicated by the Goodness of Fit Index $=0.91(\geq 0.90)$, and Root Mean Square Error of Approximation $=0.032(\leq 0.08)$. The results indicate that the construct of the measurement is suitable with the data. In addition, this research has confirmed that the spiritual attitude of high school students is constructed by seven aspects, namely resignation (tawakal), sincerity (ikblas), thankfulness (syukur), patience (shabr), fear (khauf), hopefulness (raja'), and righteousness (takwa).
\end{abstract}

Keywords: spiritual attitude, validity, reliability

\section{Introduction}

In the last decade, many people have been looking for the meaning and purpose of their lives as well as some spiritual experiences. It has been continuously emerged in the recent studies which have been presented by a number of researchers (Brown, 2007; Fisher, 2013). Although it has been discussed in many studies, the exact definition of spiritual experience has not been clearly explained yet. Further, the circumstance of spirituality itself can be indicated by the meaning of human life although how people intended and interpreted the meaning of life satisfaction is still being investigated (Smither \& Khorsandi, 2009).
Spirituality can be interpreted as an understanding related to human identity, their ethic, and their way of life. Besides, it also explains a fundamental element that makes people full of energy and reveals the state of feeling which is integrated with overall internal human resources in the meaning beyond their religious belief (Min \& Yun, 2015). In fact, spirituality dimension is almost always identified as being equal to the religious state. Furthermore, in order to support the previous statement, it is found that people with highly religious state are typically more spiritual, although it is somewhat at a lesser extent (Bryant, Choi, \& Yasuno, 2003; Nikfarjam, Heidari-Soureshjani, Khoshdel, Asmand, \& Ganji, 2017). 
The meaning of spirituality as a psychometric property has been variously defined. However, declaring the exact meaning of spirituality becomes a difficult thing (Fisher, 2016). There is no specific term which can describe how spirituality is explained. The most unclear discussion of the spiritual aspect is emphasized on the issue of the transcendental element (Koenig, 2009).

One such study implies that spirituality, as a complex construct, includes existential and also religious dimensions (Hungelmann, Kenkel-Rossi, Klassen, \& Stollenwerk, 1996). It refers to the affective experiences of positive feelings from the person's ability to understand the purpose in life - related to personal, communal, and transcendental aspects (Soleimani et al., 2017). Religious dimension as the transcendental aspect in the construct of spirituality can be determined as a person's qualification and his/her ability to control his/her feelings related to how he/she interprets and makes a reflection of his/her religious belief. Furthermore, spirituality is not only evolved in terms of religious dimensions, but also becomes one of the most prominent subjects in the media and various disciplines, also in many salient factors especially in human health integrated with the internal forces (Azarsa, Davoodi, Markani, Gahramanian, \& Vargaeei, 2015; Moberg, 2002).

Another outstanding theory explains spirituality as a personal belief in God or a higher power in the religious adherents (Good \& Willoughby, 2006). In addition, Shodiq, Zamroni, and Kumaidi (2016) assert that as a transcendental element, spirituality in Islamic studies and in terms of Islamic faith has two dimensions, namely: belief (tashdiq-al-qalb) which is known as rukun iman, and also attitude or personal feeling (amal-al-qalb) which has seven aspects i.e. thankfulness (syukur), fear (khauf), love (mababbah), patience, resignation (tawakkal), hopefulness (raja), and sincerity (ikhlas). In the same term of Islamic studies, spirituality based on a Moslem perspective centers on loving submission and closeness to God (Ghorbani, Watson, Geranmayepour, \& Chen, 2014).

Spirituality and religiosity are often used interchangeably, but the two concepts are very different. Sheridan and Hemert (1999) define spirituality as a human search for the purpose and meaning of life experience, while Tanyi (2002) argues that spirituality is a personal search for the purpose and meaning in life. Spirituality entails connection to religious beliefs or self-chosen faith. The two previous definitions are almost the same thing, but there is a slight difference. Spirituality according to the first description is emphasized on the meaning of life experience, while the second is focused on the meaning in life.

According to Hill et al. (2000), the term 'spirituality' can be used to describe 'one's religious experiences,' while the term 'religiosity' is used to express 'the state of belief.' Spirituality in the general view seems more basic, positive, and sincere while religiosity implies the ritual and obedience in worship related to certain religious adherents.

One of the most important and fundamental concepts in social psychology is attitudinal competence (Bidjari, 2011). Fishbein and Ajzen (1975) define attitude as a person's location on a bipolar evaluation of affective dimension concerning some objects, viewed as predisposing the individual to do various overt behaviours. Likewise, attitude refers to the people's predisposition to respond consistently whether they like the object or not (Mardapi, 2017, p. 134). The term 'bipolar evaluation of affective dimension' can be described as the state of positive and negative feeling onto the particular object. The attitude in this way consists of the positive and negative direction.

According to Kusaeri and Suprananto (2012, p. 206), like the previous explanation, attitudinal competence is defined as a state of readiness to react to an object in a certain way as a form of evaluation and reflection of feeling. Furthermore, Sax (1980, p. 493) emphasizes the characteristics of attitude which contains some dimensions, i.e. direction, intensity, pervasiveness, consistency, and salience.

In relation to the spiritual term, attitude can be explained as a person's predisposition to choose his/her response to the prevalent situation with an internalization of specific dimension correlating with his/her religious understanding and spiritual conception. Spiritual 
attitude is more often identified as the same as religious attitude. Hill et al. (2000) affirm that both spirituality and religiosity have been recognized as having a relationship with a person's mental health status and are relevant to the study of personality and in the genetic determinants of personality. Further, Huber and Huber (2012) state that the dimensions of spiritual attitude can be seen from the ideology, private practice, religious experience, and intellectual dimensions that are considered representing the totally religious life.

Although it is hardly practical to discuss the spirituality definition and its relation, which is a multidimensional concept (Cook, 2004; Hill et al., 2000) including such domains as personal, communal, environmental, and transcendental (Fisher, 2016), the measure of spirituality is more popular in the field of mental health, human existence, and social well-being research. However, this major property of psychometric related to the existential and religious dimensions is infrequently and less practiced in the scope of education, especially in student achievement and academic behaviour.

The spiritual attitude in terms of educational learning and curriculum is a student's qualification of ability to control him/herself and his/her description of spiritual selfcoping. It is associated with the character building in education which is intended to build a moral, democratic, and religious student as the best outcome in educational learning. The spiritual attitude illustrates the increase of vertical interaction and the strong relationship with God (Ministry of Religious Affairs of Republic of Indonesia, 2014, p. 8). The spirituality and spiritual attitude are gaining popularity within educational curriculum and academics as the discussions regarding the prominence of spiritual attitude in education increase.

Based on the perspective of a Moslem, spiritual attitude is related to the faith, centered on loving submission and closeness to God which can be seen from his/her religious experience, private practice, and social relationship. This study is intended to develop an instrument to measure Moslems' spiritual attitude in education with the seven subscales drawn from the Islamic religious term named resignation (tawakkal), sincerity (ikblas), thankfulness (syukur), patience (shabr), fear (khauf), hopefulness (raja'), and righteousness (takwa). This study is also intended to test the instrument construct validity and estimate the instrument reliability through quantitative analysis of the data obtained from the research sample.

\section{Method}

This study is a research and development ( $R$ \& D) study employing the quantitative approach. It is aimed at developing an instrument to measure Moslems' spiritual attitude in education for high school students. The research procedure was carried out through four stages, namely: (a) determining conceptual definition, (b) determining operational definition, (c) drawing indicators, and (d) constructing instrument.

\section{Population and Sample}

This research was conducted at 11 public senior high schools in Yogyakarta, Indonesia. The population was the grade XI Moslem students, and the sample was 307 participants established by using the cluster random sampling technique by considering students' focus of study, MIA (Mathematics and natural science) and IS (Social science) as the cluster. The number of the sample respondents is shown in Table 1.

Table 1. The numbers of sample respondents

\begin{tabular}{cc}
\hline School Name & Amount \\
\hline SMA Negeri 2 Yogyakarta & 78 \\
SMA Negeri 4 Yogyakarta & 89 \\
SMA Negeri 7 Yogyakarta & 79 \\
SMA Negeri 10 Yogyakarta & 61 \\
Total & $\mathbf{3 0 7}$ \\
\hline
\end{tabular}

\section{Data Collecting Technique}

The instrument to measure Moslems' spiritual attitude was developed by using the seven subscales drawn from the Islamic religious terms, and contained 24 indicators. Those indicators were developed into 35 items of questionnaire using three-point alternative response model $(\mathrm{a}, \mathrm{b}$, and $\mathrm{c}$ ) of the 
summated rating scale and designed to the multiple-choice form of questionnaires with the variant score of key answer $(1-3)$. The conceptual framework of Moslems' spiritual attitude in this research is shown in Figure 1.

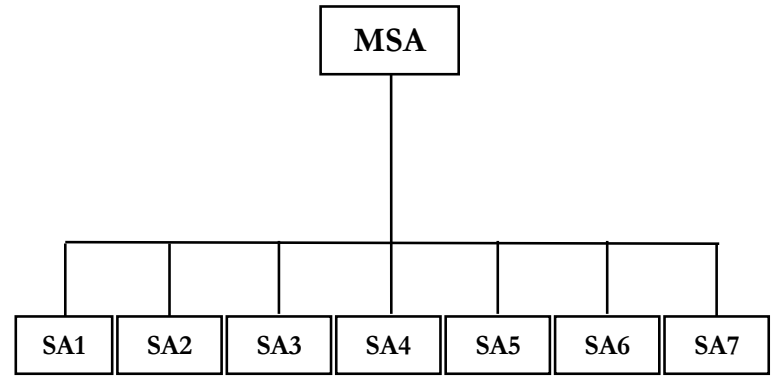

Figure 1. The conceptual framework of Moslems' spiritual attitude

Notes:

MSA : Moslems' Spiritual Attitude

SA1 : Resignation (Tawakal)

SA2 : Sincerity (Ikblas)

SA3 : Thankfulness (Syukur)

SA4 : Patience (Shabr)

SA5 : Fear (Khauf)

SA6 : Hopefulness (Raja')

SA7 : Righteousness (Takwa)

The Moslems' spiritual attitude (MSA) has seven subscales. The first subscale is resignation (Tawakal), which refers to the state of self-resignation to obey in worship and to accept all Allah's decision. The second subscale is sincerity (Ikblas), the term which refers to being sincere to do a favor. The third subscale is thankfulness (Syukur), referring to admitting all Allah's best creatures and feeling happy to do His order and leaving His prohibition. The fourth subsclae is patience (Shabr), referring to the attitude of being consistent to refrain himself from ugliness. The fifth subscale is fear (Khauf), being afraid of Allah. The sixth subscale is hope (Raja'), hoping and asking for His grace and forgiveness. The last subscale is righteousness (Takwa), which is the Islamic concept of having self-restraint.

\section{Content Validity}

The developed items in this research instrument were validated by the five panels of judges and regarded as the expert-judgement. The Aiken's V formula was used to assess the feasibility of the content validity. The lecturers of Educational Measurement and Islamic studies were involved in the panel. All of the experts were selected based on their experiences in the field of educational measurement, psychometrics, and Islamic studies.

The validators as the experts assess the whole instrument by giving scores to the developed items and give responses to the instrument's indicator through comments and suggestions. Subsequently, the validators' suggestions and comments become the basis for making a relevant improvement which will be used to rewrite the items of the research instrument.

\section{Construct Validity}

Construct validity needs a definition with the specified conceptual circumscription and more focused on particular attributes of the variable than concerned with the values or scores gained from the instrument (Salkind, 2000). Construct validity emphasizes on logical analysis and investigates the relationships of the data analysis based on theoretical consideration.

Construct validity explains the extent to which performance on the test is consistent with the constructs in a particular theoretical consideration. The present study is also concerned with investigating the construct validity for the research instrument to test how the instrument is consistent with the spiritual attitudes construct.

The result of the confirmatory factor analysis produced a standardized loading factor (SLF) and was determined as the construct validity. Once the SLF value of the certain indicator is over 0.30 , the indicator is considered as significant (Igbaria, Zinatelli, Cragg, \& Cavaye, 1997, p. 290). Another evidence of the construct validity is also determined by the significant $t$-value ( $t$-value $>1.96$ ) which uses the confidence interval of 0.05 .

\section{Goodness of Fit Statistics}

The fit statistics of the instrument in this study refers to the fulfilment of two of the three models of fit criteria, i.e. Root Mean Square Error of Approximation (RMSEA $\geq 0.08$ ), p-value $\geq 0.05$ and Goodness of Fit Index (GFI 
$\geq 0.90$ ) (Suranto, Muhyadi, \& Mardapi, 2014, p. 102). Hair, Black, Babin, and Anderson (2010, p. 656) explain that RMSEA is the fittest statistics to be used in the confirmatory factor analysis. The Goodness of Fit statistics was used in this research to investigate the fit statistics between the primary data obtained from the research sample and the theoretical consideration. The fulfillment of the two models of fit criteria described that the construct of measurement was suitable to the data.

Table 2. Parameter of fit statistics

\begin{tabular}{ccc}
\hline Goodness of Fit & Cut off Point & Notes \\
\hline Chi-Square (p-value) & p-value $\geq 0.05$ & Model Fit \\
RMSE $A$ & RMSE $A \geq 0.08$ & Model Fit \\
Goodness of Fit Index (GFI) & GFI $\geq 0.90$ & Model Fit \\
\hline
\end{tabular}

\section{Data Analysis}

The score given from the five experts' judgement for the total items in the research instrument was subsequently analyzed with the Aiken's $V$ formula to investigate the content validity of the instrument. The content validity analysis was used prior to the dissemination of the research instrument. The primary data obtained from the research instrument were analyzed using Lisrel 8.80 software program.

To analyze the quantitative data, two statistical procedures were employed to answer the research question. First, the secondorder Confirmatory Factor Analysis was applied to obtain the construct validity for the instrument based on the standardized loading factor and to investigate the fit statistics of the instrument construct. Second, the coefficient omega or construct reliability and Average Variance Extracted formula was applied to estimate the reliability coefficient of the instrument.

The fit statistics of the instrument was obtained from the output of the second-order Confirmatory Factor Analysis. RMSEA and GFI were used to determine the instrument fit statistics.

\section{Findings and Discussion}

This study is aimed to develop an instrument to measure Moslems' spiritual attitude as an inventory model. To achieve these goals, a number of respondents were involved as the research sample to obtain the quantitative data based on their responses to the questionnaires. The score gained by using the instrument was used to test the construct validity and the coefficient of instrument reliability through the data analysis.

The construct dimension of Moslems' spiritual attitude in this study includes seven aspects developed into 24 indicators. The seven aspects include resignation (tawakkal), sincerity (ikhlas), thankfulness (syukur), patience (shabr), fear (khauf), hopefulness (raja'), and righteousness (takwa). The establishment of the Moslems' spiritual attitude construction was based on the experts in Islamic studies, psychometry, and educational evaluation, as well as the general practitioners of Islamic education in several high schools.

The 35 items of the questionnaire were validated using Aiken's $\mathrm{V}$ formula to assess the feasibility of the content validity. The Aikens' $\mathrm{V}$ index ranged from 0.80 to 0.95 which can be interpreted that all the items which were developed from certain indicators in this research instrument have a good content validity. The validator's response reveals that the developed instrument in this research is a suitable instrument to measure Moslems' spiritual attitude in education.

\section{Confirmatory Factor Analysis}

The conceptual construct and the analysis result of the developed instrument with second-order CFA are presented in Figure 2. The analysis result of the second order CFA as indicated in Figure 2 shows that the model designed in this study complies with the goodness of fit statistics. The model fit of the instrument is indicated by the RMSEA = 0.032 and Goodness of Fit Index $=0.91$. 


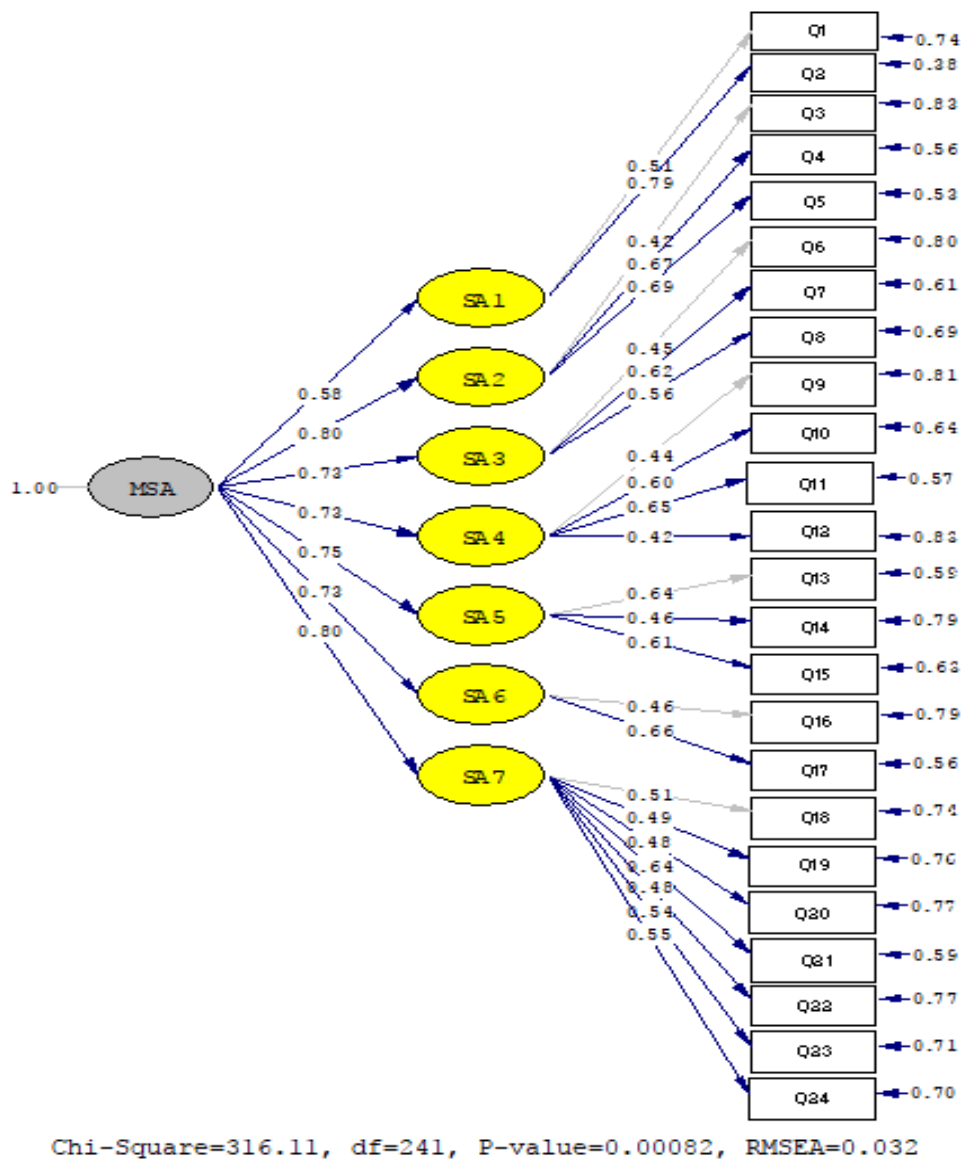

Figure 2. The result of CFA second order of Moslem's spiritual attitude

Notes:

Q1 : Self-resignation to obey in worship

Q2 : Recognizing human's limitation

Q3 : Not to expect any rewards

Q4 : Not to be careless in praise

Q5 : Not to be hopeless at failure

Q6 : Admitting all Allah's best creatures

Q7 : Using God's grace for good

Q8 : Not using the grace for ugliness

Q9 : Being consistent with Allah's commandment

Q10 : Being consistent with Allah's prohibition

Q11 : Being consistent to tell the good

Q12 : Being grateful for the tragedy and hardship

Q13 : Feeling guilty for disregarding Allah's commandment

Q14 : Feeling guilty for breaking Allah's prohibition

Q15 : Being afraid of His threat

Q16 : Hoping for Allah's grace

Q17 : Asking for His forgiveness

Q18 : Making shalat a priority in life

Q19 : Paying for zakat

Q20 : Being tolerant

Q21 : Being honest

Q22 : Rejecting adultery

Q23 : Not to use other's property

Q24 : Not breaking promises
The value of Standardized Loading Factor as the result of the second-order CFA is presented in Figure 2, while the t-value and $\mathrm{R}^{2}$ of the instrument indicators are shown in Table 3.

The result of the second-order confirmatory factor analysis indicates that the 24 indicators in the conceptual construct of the Moslems' spiritual attitude are considered significant based on the $t$-value index. It is shown by the t-value $>1.96$ in which the lowest t-value is 3.83 (Q5) and the highest is 5.78 (Q21). Another evidence is shown by the value of standardized loading factor based on the result of the second-order CFA which is shown in Table 3. It indicates that the entire indicators have the value of SLF $>0.30$ (the lowest value of SLF is 0.42 while the highest is 0.79$)$. The evidence of the $t$-value index and the standardized loading factor in this instrument research can be identified as an acceptable construct validity and suitable instrument to measure Moslems' spiritual attitude in education. 
Table 3. The result of second order CFA of Moslems' spiritual attitude

\begin{tabular}{ccccl}
\hline Indicator & $\begin{array}{c}\text { Loading } \\
\text { Factor }\end{array}$ & t-value & $\mathbf{R}^{2}$ & \multicolumn{1}{c}{ Notes } \\
\hline Q1 & 0.51 & - & 0.26 & Reference Var \\
Q2 & 0.79 & 4.70 & 0.62 & Indicator Fit \\
Q3 & 0.42 & - & 0.17 & Reference Var \\
Q4 & 0.67 & 4.59 & 0.44 & Indicator Fit \\
Q5 & 0.69 & 3.83 & 0.47 & Indicator Fit \\
Q6 & 0.45 & - & 0.20 & Reference Var \\
Q7 & 0.62 & 5.13 & 0.39 & Indicator Fit \\
Q8 & 0.56 & 4.90 & 0.31 & Indicator Fit \\
Q9 & 0.44 & - & 0.19 & Reference Var \\
Q10 & 0.60 & 4.16 & 0.36 & Indicator Fit \\
Q11 & 0.65 & 4.86 & 0.43 & Indicator Fit \\
Q12 & 0.42 & 4.34 & 0.17 & Indicator Fit \\
Q13 & 0.64 & - & 0.41 & Reference Var \\
Q14 & 0.46 & 4.19 & 0.21 & Indicator Fit \\
Q15 & 0.61 & 4.77 & 0.37 & Indicator Fit \\
Q16 & 0.46 & - & 0.21 & Reference Var \\
Q17 & 0.66 & 4.04 & 0.44 & Indicator Fit \\
Q18 & 0.51 & - & 0.26 & Reference Var \\
Q19 & 0.49 & 5.28 & 0.24 & Indicator Fit \\
Q20 & 0.48 & 4.76 & 0.23 & Indicator Fit \\
Q21 & 0.64 & 5.78 & 0.41 & Indicator Fit \\
Q22 & 0.48 & 4.82 & 0.23 & Indicator Fit \\
Q23 & 0.54 & 5.07 & 0.29 & Indicator Fit \\
Q24 & 0.55 & 5.14 & 0.30 & Indicator Fit \\
\hline & & & &
\end{tabular}

Instrument Reliability

Reliability is an essential characteristic of a goodness between the test and the obtained scores. Reliability is required to obtain the instrument validity. The investigation of both validity evidence and reliability coefficient can be defined as the complementary aspects of identifying, estimating and interpreting different sources of variance in the scores (Bachman, Davidson, Ryan, \& Choi, 1995).

The reliability coefficient of the instrument was employed to test the consistency of the measurement and was used as an estimation of how much the instrument would give the same result under the same conditions. The estimation of reliability in this research was evaluated with the construct reliability (CR) and the average variance extracted (AVE). The index values of the construct reliability coefficients are presented in Table 4, and the average variance extracted for the instrument is shown in Table 5 .
Table 4. The coefficient of construct reliability of the instrument

\begin{tabular}{|c|c|c|}
\hline Aspects & $S L F$ & Errorvar \\
\hline SA1 & 0.58 & 0.66 \\
\hline SA2 & 0.80 & 0.35 \\
\hline SA3 & 0.73 & 0.47 \\
\hline SA4 & 0.73 & 0.47 \\
\hline SA5 & 0.75 & 0.44 \\
\hline SA6 & 0.73 & 0.47 \\
\hline SA 7 & 0.80 & 0.36 \\
\hline$(\Sigma S L F)^{2}$ & 26.21 & \\
\hline ¿Errorvar & & 3.19 \\
\hline$C R$ & & \\
\hline
\end{tabular}

The coefficient of construct reliability shown in Table 4 for the instrument is 0.890 . The CR formula was used to perform the internal consistency of the instrument and to test the indicator in measuring the construct of the instrument. The result of the CR computation shows that the instrument has a high reliability index and is considered to have a good consistency to measure Moslems' spiritual attitude in education.

Table 5. The coefficient of average variance extracted (AVE) of the instrument

\begin{tabular}{ccc}
\hline Aspects & $\boldsymbol{S L F}^{2}$ & Errorvar \\
\hline SA1 & 0.34 & 0.66 \\
SA2 & 0.64 & 0.35 \\
SA3 & 0.53 & 0.47 \\
SA4 & 0.53 & 0.47 \\
SA5 & 0.56 & 0.44 \\
SA6 & 0.53 & 0.47 \\
SA7 & 0.64 & 0.36 \\
$\boldsymbol{\Sigma}\left(\boldsymbol{S L F} \boldsymbol{F}^{2}\right.$ & 3.78 & \\
$\boldsymbol{\Sigma}$ Errorvar & & 3.19 \\
$\boldsymbol{A} \boldsymbol{V E}$ & & $\mathbf{0 . 5 4 2}$ \\
\hline
\end{tabular}

The average variance extracted (AVE) is used to measure the number of variances that can be captured by certain constructs compared to the variances produced by the error of measurement. Table 5 shows that the developed instrument has a moderately good average variance extracted estimation and been proven by the computation of 0.542 (slightly above 0.50 ) for the entire subscales in the Moslems' spiritual attitude instrument.

\section{Conclusion}

The construct of Moslems' spiritual attitude is determined by Islamic religious terms. The instrument of the study is an inventory which is defined as a self-report model of the 
summated rating scale and designed for the multiple-choice form of the questionnaire using three-point (1-3) alternative responses. The instrument contains 35 item questionnaire called Moslems' spiritual attitude scale.

The Moslems' spiritual attitude dimension in education means students' attitude or personal feeling in self-condition related to their religious experience, ideology, and private practice in terms of relation with God and interaction with Him. The Moslem's spiritual attitude consists of seven aspects as the latent variable and was developed into 24 indicators as the variable observed. .

The construct validity of the Moslems' spiritual attitude scale is considered as moderately high according to the standardized loading factor (SLF) value. The value of SLF as the result of the second-order confirmatory factor analysis for the 24 instrument indicators is above 0.30 , ranging from 0.42 to 0.79 . The computation result for the coefficient of construct reliability (CR) of the instrument is 0.890 while the average variance extracted (AVE) is 0.542 .

The fit statistics produces a model fit as indicated by the Root Mean Square Error of Approximation (RMSEA) $=0.032(<0.08)$, and Goodness of Fit Index (GFI) $=0.91$. The result indicates that the construct of the measurement is suitable to the data. The model is also suitable for estimating the covariance matrix of the population which means that there is no difference from the sample respondents in this study. According to the reseach findings, it can be concluded that Moeslem's spiritual attitude is constructed by seven aspects, namely resignation (tawakkal), sincerity (ikblas), thankfulness (syukur), patience (shabr), fear (khauf), hopefulness (raja'), and righteousness (takwa).

\section{References}

Azarsa, T., Davoodi, A., Markani, A. K., Gahramanian, A., \& Vargaeei, A. (2015). Spiritual wellbeing, attitude toward spiritual care and its relationship with spiritual care competence among critical care nurses. Journal of Caring Sciences, 4(4), 309-320. https://doi.org/ $10.15171 /$ jcs. 2015.031
Bachman, L. F., Davidson, F., Ryan, K., \& Choi, I. C. (1995). An investigation into the comparability of two tests of English as a foreign language: The Cambridge TOEFL comparability study. Cambridge: Cambridge University Press.

Bidjari, A. F. (2011). Attitude and social representation. Procedia - Social and Behavioral Sciences, 30, 1593-1597. https://doi.org/10.1016/j.sbspro.2011. 10.309

Brown, C. G. (2007). Secularization, the growth of militancy and the spiritual revolution: Religious change and gender power in Britain, 1901-2001. Historical Research, 80, 393-418. https://doi.org/ 10.1111/j.1468-2281.2007.00417.x

Bryant, A. N., Choi, J. Y., \& Yasuno, M. (2003). Understanding the religious and spiritual dimensions of students' lives in the first year of college. Journal of College Student Development, 44(6), 723-745. https://doi.org/10.1353/csd.2003.0063

Cook, C. C. (2004). Addiction and spirituality. Addiction, 99(5), 539-551. https://doi. org/10.1111/j.1360-0443.2004.00715.x

Fishbein, M., \& Ajzen, I. (1975). Belief, attitude, intention, and behavior: An introduction to theory and research. Reading, MA: Addison-Wesley.

Fisher, J. (2013). Assessing spiritual wellbeing: Relating with God explains greatest variance in spiritual well-being among Australian youth. International Journal of Children's Spirituality, 18(4), 306-317. https://doi.org/ 10.1080/1364436X.2013.844106

Fisher, J. (2016). Selecting the best version of SHALOM to assess spiritual well-being. Religions, 7(5), $45 . \quad$ https:// doi.org/10.3390/rel7050045

Ghorbani, N., Watson, P. J., Geranmayepour, S., \& Chen, Z. (2014). Measuring Muslim spirituality: Relationships of Muslim experiential religiousness with religious and psychological adjustment in Iran. Journal of Muslim Mental Health, 
8(1). https://doi.org/http://dx.doi.org /10.3998/jmmh.10381607.0008.105

Good, M., \& Willoughby, T. (2006). The role of spirituality versus religiosity in adolescent psychosocial adjustment. Journal of Youth and Adolescence, 35(1), 39-53. https://doi.org/

10.1007/s10964-005-9018-1

Hair, J. F., Black, W. C., Babin, B. J., \& Anderson, R. E. (2010). Multivariate data analysis (7th ed.). Upper Saddle River, NJ: Prentice Hall.

Hill, P. C., Pargament, K. I., Hood, R. W., McCullough, J. M. E., Swyers, J. P., Larson, D. B., \& Zinnbauer, B. J. (2000). Conceptualizing religion and spirituality: Points of commonality, points of departure. Journal for the Theory of Social Behaviour, 30(1), 51-77. https:// doi.org/10.1111/1468-5914.00119

Huber, S., \& Huber, O. W. (2012). The centrality of religiosity scale (CRS). Religions, 3(3), 710-724. https:// doi.org/10.3390/rel3030710

Hungelmann, J., Kenkel-Rossi, E., Klassen, L., \& Stollenwerk, R. (1996). Focus on spiritual well-being: Harmonious interconnectedness of mind-bodyspirit-use of the JAREL spiritual wellbeing scale: Assessment of spiritual well-being is essential to the health of individuals. Geriatric Nursing, 17(6), 262266. https://doi.org/10.1016/S01974572(96)80238-2

Igbaria, M., Zinatelli, N., Cragg, P., \& Cavaye, A. L. M. (1997). Personal computing acceptance factors in small firms: A structural equation model. MIS Quarterly, 21(3), 279-305. https:// doi.org/10.2307/249498

Koenig, H. G. (2009). Research on religion, spirituality, and mental health: A review. The Canadian Journal of Psychiatry, 54(5), 283-291. https://doi.org/ 10.1177/070674370905400502

Kusaeri, \& Suprananto. (2012). Pengukuran dan penelitian pendidikan. Yogyakarta: Graha Ilmu.
Mardapi, D. (2017). Pengukuran, penilaian, dan evaluasi pendidikan (2nd ed.). Yogyakarta: Parama Publishing.

Min, S., \& Yun, S. (2015). A study on the differences between spiritual wellbeing and sexual attitude considering the type of university. Indian Journal of Science and Technology, 8(S1), 54-58. https://doi. org/10.17485/ijst/2015/v8iS1/57582

Ministry of Religious Affairs of Republic of Indonesia. (2014). Model penilaian pencapaian kompetensi peserta didik madrasah tsanawiyah (MTs). Jakarta: Directorate General of Islamic Education.

Moberg, D. O. (2002). Assessing and measuring spirituality: Confronting dilemmas of universal and particular evaluative criteria. Journal of Adult Development, 9(1), 47-60. https://doi.org /10.1023/A:1013877201375

Nikfarjam, M., Heidari-Soureshjani, S., Khoshdel, A., Asmand, P., \& Ganji, F. (2017). Comparison of spiritual wellbeing and social health among the students attending group and individual religious rites. World Family Medicine Journal, 15(8), 160-165. https://doi. org/10.5742/MEWFM.2017.93071

Salkind, N. J. (2000). Exploring research. Michigan, MI: Prentice Hall.

Sax, G. (1980). Principles of educational and psychological measurement and evaluation. California, CA: Wadsworth.

Sheridan, M. J., \& Hemert, K. A. (1999). The role of religion and spirituality in social work education and practice: A survey of student views and experiences. Journal of Social Work Education, 35(1), 125-141. https://doi.org/ 10.1080/10437797.1999.10778952

Shodiq, S., Zamroni, Z., \& Kumaidi, K. (2016). Developing an instrument for measuring the faith of the students of Islamic senior high school. REiD (Research and Evaluation in Education), 2(2), 181-193. https://doi.org/ 10.21831/reid.v2i2.11117 
Smither, R., \& Khorsandi, A. (2009). The implicit personality theory of Islam. Psychology of Religion and Spirituality, 1(2), 81-96. $10.1037 /$ a0015737

Soleimani, M. A., Sharif, S. P., Allen, K. A., Yaghoobzadeh, A., Nia, H. S., \& Gorgulu, O. (2017). Psychometric properties of the Persian version of spiritual well-being scale in patients with acute myocardial infarction. Journal of Religion and Health, 56(6), 1981-1997. https://doi.org/10.1007/s10943-0160305-9
Suranto, S., Muhyadi, M., \& Mardapi, D. (2014). Pengembangan instrumen evaluasi uji kompetensi keahlian (UKK) administrasi perkantoran di SMK. Jurnal Penelitian Dan Evaluasi Pendidikan, 18(1), 98-114. https://doi.org/ 10.21831/pep.v18i1.2127

Tanyi, R. A. (2002). Towards clarification of the meaning of spirituality. Journal of Advanced Nursing, 39(5), 500-509. https://doi.org/10.1046/j.13652648.2002.02315.x 